\title{
Chemical Constituents of Cymodocea rotundata Asch. and Schweinf
}

\author{
Judy D. V. Perez ${ }^{1,2}$, Chien Chang Shen ${ }^{3}$, Consolacion Y. Ragasa ${ }^{4 *}$
}

\section{Judy D.V. Perez ${ }^{1,2}$, Chien Chang Shen ${ }^{3}$, Consolacion Y. Ragasa ${ }^{1,4^{*}}$}

'Chemistry Department, De La Salle University, 2401 Taft Avenue, Manila 1004, PHILIPPINES.

${ }^{2}$ Natural Science Department, College of Arts and Sciences, Ateneo de Naga University, P. Santos St, Peñafrancia, Naga, Camarines Sur, PHILIPPINES. ${ }^{3}$ National Research Institute of Chinese Medicine, Ministry of Health and Welfare, 155-1, Li-Nong St., Sec. 2, Taipei 112, TAIWAN.

${ }^{4}$ Chemistry Department, De La Salle University Science and Technology Complex Leandro V. Locsin Campus, Biñan City, Laguna 4024, PHILIPPINES.

Correspondence

Consolacion Y Ragasa

Chemistry Department, De La Salle University Science and Technology Complex Leandro V. Locsin Campus, Biñan City, Laguna 4024, PHILIPPINES.

E-mail: consolacion.ragasa@dlsu.edu.ph

History

- Submission Date: 01-01-2018;

- Review completed: 14-02-2018;

- Accepted Date: 05-03-2018

DOI : 10.5530/pj.2018.4.101

Article Available online

http://www.phcogj.com/v10/i4

Copyright

(C) 2018 Phcog.Net. This is an openaccess article distributed under the terms of the Creative Commons Attribution 4.0 International license.

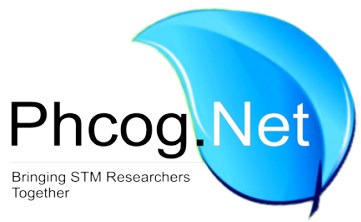

\begin{abstract}
Introduction: Cymodocea rotundata Asch. and Schweinf, a widespread seagrass with reported antimicrobial activity, was investigated for its chemical constituents. Methods: The compounds were isolated by silica gel chromatography and identified by NMR spectroscopy. Results: This study has led to the isolation of $\beta$-sitosteryl-3 $\beta$-glucopyranoside-6'-O-fatty acid esters (1), chlorophyll a (2) and a mixture of $\beta$-sitosterol (3a) and stigmasterol $\mathbf{3} \mathbf{3} \mathbf{b})$ in about 1:1 ratio from the dichloromethane extract of $C$. rotundata. Conclusion: This is the first report on the isolation of $\mathbf{1 - 3} \mathbf{b}$ from $C$. rotundata. Compounds $\mathbf{2 - 3 \mathbf { b }}$ were reported to exhibit antibacterial activity and may be partly responsible for the reported antimicrobial activity of the $C$. rotundata extract.

Key words: Cymodocea rotundata, Cymodoceaceae, $\beta$-sitosteryl-3 $\beta$-glucopyranoside-6'-Ofatty acid esters, Chlorophyll , $\beta$-sitosterol, Stigmasterol.
\end{abstract}

\section{INTRODUCTION}

Cymodocea rotundata is a widespread seagrass that occurs in shallow water, on sand-mud in sheltered coves or bays, lagoons, mouth of rivers and coral reefs throughout the Philippines. ${ }^{1}$ It has a wide IndoPacific distribution and is relatively common within its range. ${ }^{2}$ C. rotundata extracts exhibited predominant growth inhibitory activity against UTI bacteria ${ }^{3}$ and human pathogens. ${ }^{4,5}$ Phytochemical analysis of C. rotundata extracts indicated the presence of tannins, saponins, resins, proteins, acidic compounds, reducing sugars, terpenoids, cardiac glycosides and alkaloids. ${ }^{4}$ Another study reported that $C$. rotundata contained vitamin C (28.43 $\mathrm{mg} \mathrm{g}^{-1}$ ) and p-coumaric acid. C. rotundata extracts gave a total antioxidant activity of $6.65 \mathrm{mg}$ ascorbic acid equivalent/g and was found to be a potent DPPH radical scavenger $(70.30 \%){ }^{6}$

This study is part of our research on the chemical constituents of seagrasses found in the Philippines. We earlier reported the isolation of bis(2-ethylhexyl) phthalate, chlorophyll a, $\beta$-sitosterol and stigmasterol from Cymodocea serrulata. ${ }^{7}$ We report herein the isolation of $\beta$-sitosteryl-3 $\beta$-glucopyranoside-6'-Ofatty acid esters (1), chlorophyll a (2) and a mixture of $\beta$-sitosterol (3a) and stigmasterol (3b) from C. rotundata. To the best of our knowledge, this is the first report on the isolation of $\mathbf{1 - 3 b}$ from C. rotundata.

\section{MATERIALS AND METHODS}

NMR spectra were recorded on a Varian VNMRS spectrometer in $\mathrm{CDCl}_{3}$ at $600 \mathrm{MHz}$ for ${ }^{1} \mathrm{H} \mathrm{NMR}$ and $150 \mathrm{MHz}$ for ${ }^{13} \mathrm{C}$ NMR spectra. Column chromatography was performed with silica gel 60 (70-230 mesh).
Thin layer chromatography was performed with plastic backed plates coated with silica gel $\mathrm{F}_{254}$ and the plates were visualized by spraying with vanillin/ $\mathrm{H}_{2} \mathrm{SO}_{4}$ solution followed by warming.

\section{Sample Collection}

Samples of the leaves of Cymodocea rotundata Asch. and Schweinf. were collected from the seagrass meadow of Caramoan, Camarines Sur Philippines in September 2016. The samples were authenticated at the Botany Division, Philippine National Museum.

\section{General Isolation Procedure}

A glass column 6 inches in height and 0.25 inch internal diameter was used for the chromatography. The crude extracts were fractionated by silica gel chromatography using increasing proportions of acetone in $\mathrm{CH}_{2} \mathrm{Cl}_{2}$ at $10 \%$ increment by volume as eluents. Five milliliter fractions were collected. Al fractions were monitored by thin layer chromatography. Fractions with spots of the same $R f$ values were combined and rechromatographed in appropriate solvent systems until TLC pure isolates were obtained. Final purifications were conducted using Pasteur pipettes as columns. One milliliter fractions were collected.

\section{Isolation of the Chemical Constituents from the Leaves of $C$. rotundata}

The air-dried C. rotundata $(50 \mathrm{~g})$ leaves were ground in a blender, soaked in $\mathrm{CH}_{2} \mathrm{Cl}_{2}$ for 3 days and then filtered. The solvent was evaporated under vacuum to afford a crude extract $(0.3 \mathrm{~g})$ which was chromato- 
graphed using increasing proportions of acetone in $\mathrm{CH}_{2} \mathrm{Cl}_{2}$ at $10 \%$ increment by volume. The $10 \%$ acetone in $\mathrm{CH}_{2} \mathrm{Cl}_{2}$ fraction was rechromatographed using 10\% EtOAc in petroleum ether. The less polar fractions were combined and rechromatographed using 10\% EtOAc in petroleum ether to afford 2 ( $4 \mathrm{mg}$ ) after washing with petroleum ether, followed by $\mathrm{Et}_{2} \mathrm{O}$. The more polar fractions were combined and rechromatographed $(2 \times)$ using $15 \%$ EtOAc in petroleum ether to yield a mixture of $\mathbf{3 a}$ and $\mathbf{3 b}$ (6 mg) after washing with petroleum ether. The $60 \%$ acetone in $\mathrm{CH}_{2} \mathrm{Cl}_{2}$ fraction was rechromatographed using $\mathrm{CH}_{3} \mathrm{CN}: \mathrm{Et}_{2} \mathrm{O}: \mathrm{CH}_{2} \mathrm{Cl}_{2}(1: 1: 8, \mathrm{v} / \mathrm{v})$ to afford $1(3 \mathrm{mg})$ after washing with petroleum ether.

\section{RESULTS AND DISCUSSION}

Silica gel chromatography of the dichloromethane extract of $C$. rotundata has led to the isolation of $\beta$-sitosteryl-3 $\beta$-glucopyranoside- 6 - $-O$-fatty acid esters (1), chlorophyll a (2) and a mixture of $\beta$-sitosterol (3a) and stigmasterol (3b). The NMR data of $\mathbf{1}$ are in accordance with the data reported in the literature for $\beta$-sitosteryl-3 $\beta$-glucopyranoside- 6 '- $O$-fatty acid esters; ${ }^{8} \mathbf{2}$ for chlorophyll $\mathbf{a} ;{ }^{9} \mathbf{3} \mathbf{a}$ for $\beta$-sitosterol; ${ }^{10,11}$ and $\mathbf{3 b}$ for stigmasterol. ${ }^{10,11}$

Although no biological activity tests were conducted on the isolated compounds, literature search revealed that $\mathbf{2 - 3}$ b exhibited antibacterial activities. Chlorophyll and its derivatives were reported to exhibit wound healing properties ${ }^{12}$ and antibacterial activities. ${ }^{13} \beta$-Sitosterol (3a) and stigmasterol (3b) were also reported to possess antibacterial

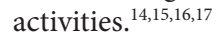

\section{CONCLUSION}

This is the first report on the isolation of $\mathbf{1 - 3 b}$ from C. rotundata. Compounds $\mathbf{2 - 3}$ b were reported to exhibit antibacterial activity and may be partly responsible for the reported antimicrobial property of the $C$. rotundata extract.

\section{ACKNOWLEDGEMENT}

A research grant from the De La Salle University Science Foundation through the URCO is gratefully acknowledged.

\section{ABBREVIATIONS}

EtOAc: ethyl acetate; Et2O: diethyl ether.

\section{CONFLICT OF INTEREST}

The authors declare no conflict of interest.

\section{REFERENCES}

1. Mefiez EG, Phillips RC, Calumpong HP. Seagrasses from the Philippines. Smithsonian Institution Press City of Washington. 1983;8.

2. Short FT, Waycott M. Cymodocea rotundata. The IUCN Red List of Threatened Species 2010: e. T173363A6999692. http://dx.doi.org/10.2305/IUCN.UK. 20103. RLTS.T173363A6999692.en. Downloaded on 25 April 2017.

3. Ragupathi R, Kannan R, Arumugam R, Anantharaman P. Chemical composition and antibacterial activity of Indian seagrasses against urinary tract pathogens. Food Chem. 2012;135(4):2470-3.

4. Mani AE, Bharathi V, Patterson J. Antibacterial activity and preliminary phytochemical analysis of sea grass Cymodocea rotundata. Int $\mathrm{J}$ Microbiol Res. 2012;2(2):99-103.

5. Ragupathi RRR, Arumugam R, lyapparaj $P$, Thangaradjou $T$, Anantharaman $P$. In vitro antibacterial, cytotoxicity and haemolytic activities and phytochemical analysis of seagrasses from the Gulf of Mannar, South India. Food Chem. 2013;136(3):1484-9.

6. Kannan RRR, Arumugam R, Thangaradjou T, Anantharaman P. Phytochemical constituents, antioxidant properties and p-coumaric acid analysis in some sea grasses. Food Res Int. 2013;54(1):1229-36.

7. Ragasa CY, Perez JDV, Shen C-C. Chemical constituents of Cymodocea serrulata R. Brown. Res J Pharm Biol Chem Sci. 2016;7(6):1630-3.

8. Ragasa CY, Ebajo Jr VD, De Los Reyes MM, Mandia EH, Brkljaca R, Urban S. Chemical Constituents of Cordia dichotoma G. Forst. J Appl Pharm Sci. 2015;5(Suppl. 2):16-21.

9. Ragasa CY, de Jesus J. Porphyrins and polyprenols from Macaranga tanarius. Res J Pharm Biol Chem Sci. 2014;5:701-8.

10. Ragasa CY, Ng VAS, De Los Reyes MM, Mandia EH, Oyong GG, Shen C-C. Chemical constituents and cytotoxicity of the leaves of Dysoxylum gaudichaudianum (A. Juss.) Miq. Der Pharma Chemica. 2014;6(5):182-7.

11. Ng VAS, Agoo EMG, Shen C-C, Ragasa CY. Chemical constituents of Cycas lacrimans. Int J Pharmacog Phytochem Res. 2015;7(3):616-20.

12. Kephart JC. Chlorophyll derivatives - Their chemistry, commercial preparation and uses. Economic Botany. 1955;9(1):3-38.

13. Mowbray S. The antibacterial activity of chlorophyll. Br Med J. 1957;1(5013):268-70.

14. Edilu A, Adane L, Woyessa D. In vitro antibacterial activities of compounds isolated from roots of Caylusea abyssinica. Ann Clin Microbiol Antimicrob. 2015;14(1):15-23.

15. Woldeyes S, Adane L, TarikuY, Muleta D, BegashawT. Evaluation of antibacterial activities of compounds isolated from Sida rhombifolia Linn. (Malvaceae); Nat Prod Chem Res. 2012;1:1-8.

16. Sen A, Dhavan P, Shukla KK, Singh S, Tejovathi G. Analysis of IR, NMR and antimicrobial activity of $\beta$-sitosterol isolated from Momordica charantia. Sci Secure J Biotech. 2012;1(1):9-13.

17. Saeidnia S, Manayi A, Gohari AR, Abdollahi M. The Story of Beta-sitosterol- A Review. Eur J Med Plants. 2014;4:590-609.

\section{SUMMARY}

\section{GRAPHICAL ABSTRACT}

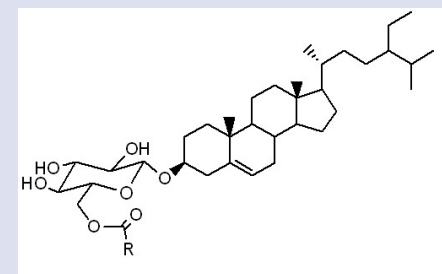

$1 \mathrm{R}=$ long chain fatty acid allyls

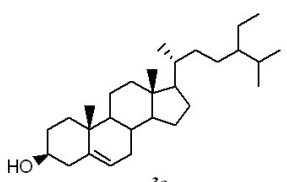

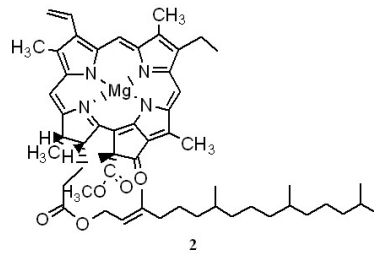

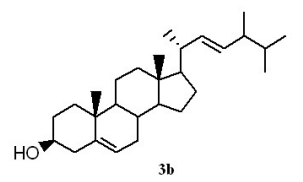

- The dichloromethane extract of $C$. rotundata afforded $\beta$-sitosteryl-3 $\beta$ glucopyranoside-6'-O-fatty acid esters (1), chlorophyll a (2) and a mixture of $\beta$-sitosterol (3a) and stigmasterol (3b). The structures of $\mathbf{1 - 3} \mathbf{3}$ were identified by NMR spectroscopy. Compounds $\mathbf{2 - 3} \mathbf{b}$ were reported to exhibit antibacterial activity which may be partly responsible for the reported antimicrobial property of the $C$. rotundata extract.

\section{ABOUT AUTHORS}

Judy Perez: Is a faculty of the College of Arts and Sciences, Ateneo de Naga University, Philippines.

Chien-Chang Shen: Is an Associate Research Fellow in Division of Chinese Medicinal Chemistry, National Research Institute of Chinese Medicine, Ministry of Health and Welfare, Taiwan, ROC.

Consolacion Y. Ragasa: Is a Full Professor of the Chemistry Department and a University Fellow of De La Salle University Manila, Philippines.

Cite this article: Perez J, Shen CC, Ragasa CY. Chemical Constituents of Cymodocea rotundata Asch. and Schweinf. Pharmacog J. 2018;10(4):620-1. 